\title{
Discussion: Effects of Plastic Waste Materials on Geotechnical Properties of Clayey Soil [DOI: 10.1007/ s40515-020-00145-4]
}

\author{
Brendan C. O'Kelly ${ }^{1}$ (D) Amin Soltani ${ }^{2}$
}

Accepted: 7 January 2022 / Published online: 21 January 2022

(C) The Author(s) 2022

Keywords Geoenvironmental risk · Plastic waste materials · Soil reinforcement

The paper under discussion (by Hassan et al. (2021)) presents a comprehensive set of experimental results from standard geotechnical laboratory tests performed on a low-plasticity clay soil (CL) amended with between $1 \%$ and $4 \%$ (by weight of dry soil) of randomly distributed discrete polyethylene terephthalate (PET) and polypropylene (PP) fibers, each blended with the soil in two fiber lengths. These fibers were prepared by cutting into two sizes waste PET water bottles and woven PP bags, each in fiber lengths of 1.0 and $2.0 \mathrm{~cm}$, and in widths of $2.5-3.0 \mathrm{~mm}$. While stated in the Abstract of their paper that "it is important to find methods to manage these waste materials without causing any ecological hazards" based on the authors' experimental bench-scale investigation, they concluded that the described PET and PP fibers can be efficiently used to improve the physical and strength properties of soil materials as foundations for engineering projects, including improvement of the CBR and resilient modulus of clayey subgrade soils for sustainable road construction.

However, the authors' experimental investigation and results, while insightful, focus solely on the geotechnical properties/performance of the clay soil-fiber mixtures, which are also compared with those of the unamended clay soil. That is, while the proposed soil reinforcement method is beneficial/smart from an engineering perspective, the authors do not present any discussion nor give any consideration to the potentially significant long-term environmental impacts that may arise from myriads of discrete plastic fibers mixed randomly with the soil in situ; an important aspect that motivated the discussers to pen this discussion contribution. In other words,

Brendan C. O’Kelly

bokelly@tcd.ie

Amin Soltani

a.soltani@federation.edu.au

1 Department of Civil, Structural and Environmental Engineering, Trinity College Dublin, Dublin D02 PN40, Ireland

2 School of Engineering, IT and Physical Sciences, Federation University, Churchill, VIC 3842, Australia 
these plastic fibers are not alienable from the soil and, as such, they cannot be recycled at the end of life of the fiber-reinforced earth structure or soil foundation. While plastic is often highly recalcitrant, over time, it can break down into tiny pieces, as micro- (between $100 \mathrm{~nm}$ and $5 \mathrm{~mm})$ and nano- $(<100 \mathrm{~nm})$ sized particles (commonly referred to as MNPs) (Jahnke et al. 2017; Alimi et al. 2018; Goli et al. 2022; O'Kelly et al. 2021), such that the possible propagation of the MNPs to the soil may lead to at least local soil and groundwater pollution in the long term. Hence, in terms of the overarching goal of sustainable road construction, a key requirement for the authors' proposed soil reinforcement method is how to isolate in a cost-effective way the plastic fiber reinforced soil layer (soil foundation) from the underlying/surrounding ground. Another aspect at the end of life of the soil foundation is the remediation of this plastic contaminated soil layer.

In the ground engineering context (with the present case considering discrete PET and PP fibers randomly mixed with clay soil), there are significant and incipient threats of MNP pollution to aquatic and terrestrial ecosystems (Abbasimaedeh et al. 2021; Goli et al. 2022; O' Kelly et al. 2021), as well as emerging negative ecological impacts on soil-plant systems and even human and animal health (Allouzi et al. 2012). For instance, significant changes have been observed in plant biomass, elemental tissue composition, root traits, leaf traits, and soil microbial activities for Allium fistulosum grown in the presence of various MNPs, including PET- and PPbased MNPs (de Souza Machado et al. 2019). Similar environmental concerns have also been raised by the discussers regarding the use of expanded polystyrene (EPS) beads-soil mixtures as lightweight fill for ground engineering applications (O'Kelly and Soltani 2022).

While the mobility of MNPs in soils remains an open question, their effects on the mobility of other contaminants of high relevance to environmental geotechnics are equally, if not more, important (O'Kelly et al. 2021). That is, MNPs act as a transport vector in soil and groundwater for other potential pollutants, including human pathogens, heavy metals, and organic contaminants (Qi et al. 2020). They can also alter the behavior of these contaminants, potentially including priority pollutants, such as plasticizers and flame retardants, which enter in the manufacturing of plastics to enhance their engineering properties (van Praagh et al. 2018). For instance, the leaching of xenobiotic compounds from various plastic products, such as phthalates and bisphenol, and the bioaccumulation of toxic chemicals within the earthworm body significantly disrupt the endocrine system of these organisms (Huerta Lwanga et al. 2016; Hodson et al. 2017; de Souza Machado et al. 2018). As such, MNPs can become an important conduit for the migration of these contaminants in the subsurface, including potentially significant negative implications for groundwater quality (O' Kelly et al. 2021).

In conclusion, the main motivation for this article is not to criticize the proposed plastic fiber soil-reinforcement method, which seems smart/beneficial from a geotechnical engineering viewpoint. Rather, the aim is to broaden the discussion and to make the geotechnical engineering community more aware of potential risks for local MNP contamination in the long term, arising from ground engineering works 
incorporating synthetic polymer-based materials, especially for those applications involving myriads of discrete plastic fibers, as reinforcement, mixed randomly with the soil in situ. It is the discussers' opinion that novel multidisciplinary research (including thorough and carefully executed environmental impact studies and assessments) of such practices as potential long-term sources for local MNP contamination in soils is paramount.

Funding Open Access funding provided by the IReL Consortium.

Open Access This article is licensed under a Creative Commons Attribution 4.0 International License, which permits use, sharing, adaptation, distribution and reproduction in any medium or format, as long as you give appropriate credit to the original author(s) and the source, provide a link to the Creative Commons licence, and indicate if changes were made. The images or other third party material in this article are included in the article's Creative Commons licence, unless indicated otherwise in a credit line to the material. If material is not included in the article's Creative Commons licence and your intended use is not permitted by statutory regulation or exceeds the permitted use, you will need to obtain permission directly from the copyright holder. To view a copy of this licence, visit http://creativecommons.org/licen ses/by/4.0/.

\section{References}

Abbasimaedeh, P., Ghanbari, A., O’Kelly, B.C., Tavanafar, M., Irdmoosa, K.G.: Geomechanical behaviour of uncemented expanded polystyrene (EPS) beads-clayey soil mixtures as lightweight fill. Geotechnics 1(1), 38-58 (2021). https://doi.org/10.3390/geotechnics1010003

Alimi, O.S., Budarz, J.F., Hernandez, L.M., Tufenkji, N.: Microplastics and nanoplastics in aquatic environments: aggregation, deposition, and enhanced contaminant transport. Environ. Sci. Technol. 52(4), 1704-1724 (2018). https://doi.org/10.1021/acs.est.7b05559

Allouzi, M.M.A., Tang, D.Y.Y., Chew, K.W., Rinklebe, J., Bolan, N., Allouzi, S.M.A., Show, P.L.: Micro (nano) plastic pollution: the ecological influence on soil-plant system and human health. Sci. Total Environ. 788, 147815 (2012). https://doi.org/10.1016/j.scitotenv.2021.147815

de Souza Machado, A.A., Kloas, W., Zarfl, C., Hempel, S., Rillig, M.C.: Microplastics as an emerging threat to terrestrial ecosystems. Glob. Change Biol. 24(4), 1405-1416 (2018). https://doi.org/10. $1111 / \mathrm{gcb} .14020$

de Souza Machado, A.A., Lau, C.W., Kloas, W., Bergmann, J., Bachelier, J.B., et al.: Microplastics can change soil properties and affect plant performance. Environ. Sci. Technol. 53(10), 6044-6052 (2019). https://doi.org/10.1021/acs.est.9b01339

Goli, V.S.N.S., Paleologos, E.K., Farid, A., Mohamed, A.M.O., O’Kelly, B.C., et al.: Extraction and characterisation of microplastics from organic solid matrices and their remediation. Environ. Geotech. (in Press) (2022). https://doi.org/10.1680/jenge.21.00072

Hassan, H.J.A., Rasul, J., Samin, M.: Effects of plastic waste materials on geotechnical properties of clayey soil. Transp. Infrastruct. Geotechnol. 8(3), 390-413 (2021). https://doi.org/10.1007/ s40515-020-00145-4

Hodson, M.E., Duffus-Hodson, C.A., Clark, A., Prendergast-Miller, M.T., Thorpe, K.L.: Plastic bag derived-microplastics as a vector for metal exposure in terrestrial invertebrates. Environ. Sci. Technol. 51(8), 4714-4721 (2017). https://doi.org/10.1021/acs.est.7b00635

Huerta Lwanga, E., Gertsen, H., Gooren, H., Peters, P., Salánki, T., et al.: Microplastics in the terrestrial ecosystem: implications for Lumbricus terrestris (Oligochaeta, Lumbricidae). Environ. Sci. Technol. 50(5), 2685-2691 (2016). https://doi.org/10.1021/acs.est.5b05478 
Jahnke, A., Arp, H.P.H., Escher, B.I., Gewert, B., Gorokhova, E., et al.: Reducing uncertainty and confronting ignorance about the possible impacts of weathering plastic in the marine environment. Environ. Sci. Technol. Lett. 4(3), 85-90 (2017). https://doi.org/10.1021/acs.estlett.7b00008

O'Kelly BC, Soltani A: Discussion of "Behaviour of a foam mixture as a lightweight construction material” [Int J of Geosynth and Ground Eng (2021) 7(3), 51]. Int. J. Geosynth. Ground Eng. (in Press) (2022).

O'Kelly, B.C., El-Zein, A., Liu, X., Patel, A., Fei, X., et al.: Microplastics in soils: an environmental geotechnics perspective. Environ. Geotech. 8(8), 586-618 (2021). https://doi.org/10.1680/jenge.20. 00179

Qi, R., Jones, D.L., Li, Z., Liu, Q., Yan, C.: Behavior of microplastics and plastic film residues in the soil environment: a critical review. Sci. Total Environ. 703, 134722 (2020). https://doi.org/10.1016/j. scitotenv.2019.134722

van Praagh, M., Hartman, C., Brandmyr, E.: Microplastics in Landfill Leachates in the Nordic Countries. Nordisk Ministerråd, Copenhagen (2018). https://doi.org/10.6027/tn2018-557

Publisher's Note Springer Nature remains neutral with regard to jurisdictional claims in published maps and institutional affiliations. 